\title{
GREEN CHEMISTRY-BASED REACTION RATE PRACTICE THROUGH ONLINE MEDIA: AN ANALYSIS OF TEACHERS' AND STUDENTS' RESPONSES
}

\author{
Afifah Nur Chamidah ${ }^{*}$, Sri Mulyanti ${ }^{2}$ \\ ${ }^{1,2}$ Departement Chemistry Education, Faculty Sciences and Technology, Universitas Islam Negeri \\ Walisongo, Semarang, Indonesia \\ *Corresponding author: afifah_1808076042@student.walisongo.ac.id
}

\begin{tabular}{ll}
\hline \hline Article Info & ABSTRACT \\
\cline { 1 - 2 } $\begin{array}{l}\text { Article history: } \\
\text { Received: June 02,2021 }\end{array}$ & $\begin{array}{l}\text { Reaction rate is one of the subjects in chemistry that students must } \\
\text { fully understand, both theoretically and skillfully. However, current } \\
\text { conditions require learning to be carried out online, including } \\
\text { Accepted: July 13,2021 } \\
\text { Published: July 31,2021 } \\
\text { online practicum on the topic of determining the order of a reaction } \\
\text { by using methods, tools, and materials that are cheap and easy to } \\
\text { obtain, this practicum as an alternative solution in learning } \\
\text { chemistry practicum during the pandemic. The practicum was } \\
\text { recorded in the form of a video to be uploaded on Youtube, then the } \\
\text { Experiment }\end{array}$ \\
$\begin{array}{l}\text { Green chemistry } \\
\text { Reaction order }\end{array}$ & $\begin{array}{l}\text { watched it. Based on the survey results from 30 respondents, the } \\
\text { practicum was stated to be very good and applicable, as seen from } \\
\text { Reaction rate }\end{array}$ \\
$\begin{array}{l}\text { the average value of the responses that were close to perfect. So it } \\
\text { can be concluded that this practicum is highly recommended for } \\
\text { teachers to apply to their students. }\end{array}$
\end{tabular}

\section{PRAKTIKUM LAJU REAKSI BERBASIS GREEN CHEMISTRY MELALUI MEDIA DARING: ANALISIS RESPON GURU DAN SISWA}

Kata Kunci:
Percobaan
Green chemistry
Orde reaksi
Laju reaksi

Green chemistry

Laju reaksi

\begin{abstract}
ABSTRAK
Laju reaksi menjadi salah satu pokok bahasan yang harus dikuasai siswa dengan utuh, baik secara teori maupun keterampilan dalam melakukan percobaan, namun kondisi saat ini pembelajaran dituntut untuk dapat dilakukan secara daring, termasuk praktikum tentang laju reaksi. Tim peneliti mencoba mendisain praktikum laju reaksi pada topik penentuan orde reaksi secara daring menggunakan metode, alat, dan bahan yang murah dan mudah didapatkan bagi siswa yang akan melakukan sendiri dari rumah, praktikum ini sebaga alternatif solusi dalam pembelajaran praktikum kimia selama masa pandemi. Praktikum dikemas dalam bentuk video yang diunggah pada media daring Youtube, selanjutnya video disebarluaskan untuk mendapat tanggapan dari responden yang menontonnya. Berdasarkan hasil survei dari 30 responden diperoleh penilaian yang sangat baik dari responden, terlihat dari nilai rata-rata tanggapan yang mendekati sempurna. Sehingga dapat disimpulkan bahwa praktikum yang dikembangkan dapat direkomendasikan bagi para guru untuk mengajarkan praktikum tentang penentuan orde reaksi bagi siswa-siswanya.
\end{abstract}




\section{INTRODUCTION}

The topic of reaction rate is part of the core activities in chemistry learning [1], The reaction rate is the foundation for mastering other chemical concepts, such as the concepts of reaction kinetics, catalysts, and thermochemistry. An understanding of chemical kinetics is related to the direction of the reaction and the reaction equilibrium, if the understanding of the reaction rate is not well understood, then the concept of the reaction shift which is determined by the rate will not be understood optimally [2]. The success of learning reaction rates is the main task for chemistry teachers, so that the purpose of mastering chemical concepts can be fully understood by students [3].

Learning the rate of a reaction must be preceded by mastering various supporting concepts, such as rate law, reaction order, rate constants, and factors that affect reaction rates [4]. The rate of a reaction is determined by many factors [4], these factors become the foundation of the speed of a reaction, so students must be able to understand them well. These factors include the concentration of the reactants, the surface area of the reactants, temperature, pressure, and the presence of a catalyst [2]-[5]. Concentration is an indicator of the number of particles of a reactant, if the particles are in large quantities it will certainly support the formation of higher products, and this is in line with the reaction rate which also increases [6], [7]. Another aspect that also plays an active role in determining the rate of reaction is temperature [8], as the reaction temperature increases, the kinetic energy of the molecules increases.

The concept of reaction rate which is supported by various other concepts is very difficult for students to understand, there are often misconceptions about the existence of temperature in increasing the reaction rate and the relation of the reaction stoichiometry calculations and its rate [5]. An understanding of the rate of a reaction is needed to understand the concept of chemistry as a whole, because the basis of chemistry is all about reactions, and the course of a reaction is determined by its speed, if the understanding of the concept of reaction rate in students is not perfect, it will be an obstacle for them to follow other chemistry topics [9], [10].

Difficulties in mastering the concepts that underlie reaction rates can be solved, one of them is by practicum learning [11], but some practicum on reaction rate learning requires tools and materials that are not cheap [11] and chemicals that only exist in the laboratory [12]. Practicum is the best medium in chemistry learning which is always synonymous with abstract concepts. The current pandemic condition is an obstacle for teachers to teach chemistry face-to-face through practical activities [13]-[15], including the topic of chemical reaction rates. So it is necessary to design a reaction rate practicum that can activate students' scientific activities (Hands on) directly without having to go to the laboratory, so that teachers can achieve learning targets and students also gain knowledge about macroscopic, sub-microscopic, and symbolic reaction rate concepts. The design of the practicum must also apply the principles of green chemistry as an effort to achieve Education Sustainable Development (ESD) which has been proclaimed by UNESCO [16]-[18]. Green chemistry is a concept that carries environmentally friendly principles by minimizing the use of toxic and hazardous materials, green chemistry has 12 principles that can be used as a reference for developing chemical experiments that are safe and do not pollute the environment, these 12 principles include: (1) prevent waste (2) maximize atomic economy (3) principles of safe synthesis (4) safe chemical products (5) use safe solvents and reagents (6) improve energy efficiency (7) use renewable raw materials ( 8) using catalysts (9) designing environmentally friendly renewable products (10) real time analysis as pollution prevention (11) avoiding the use of harmful chemicals (12) reducing process steps [19]-[20]-[21]. An example of the application of green 
chemistry principles in chemistry learning is when practicum activities are implemented using environmentally friendly materials such as the reaction between acetic acid and baking soda for reaction rate experiments, and the reaction between betadine and vitamin $\mathrm{C}$ for redox experiments.

So far, the reaction rate practicum media with balloon media only proves the presence of $\mathrm{CO}_{2}$ gas formed, and this is still in the qualitative stage, but in this study measuring the amount of concentration reacted by making a reaction barrier from the formed $\mathrm{CO}_{2}$ [22]. In this study, researchers developed an online practicum design by applying the principles of green chemistry in the study of reaction rates with easily available equipment, methods, and materials, so that students could do practical work independently at home with remote teacher guidance. This practicum aims to enable students to fully master the concepts of reaction rates, both laboratory skills and macroscopic, sub-microscopic, and symbolic knowledge of reaction rate concepts.

\section{METHOD}

The method used in this research is the survey method, which is the method used to obtain natural data with a questionnaire [23]-[26]. The survey method was carried out by giving a questionnaire containing the respondent's assessment of the reaction rate practicum video based on green chemistry. The practicum video contains a demonstration of the implementation of the green chemistry-based reaction rate practicum. The purpose of this study is to develop a reaction rate practicum that focuses on determining the order of a reaction to provide recommendations to teachers regarding the design of a reaction rate practicum that uses easily available tools and materials and methods that are easy to do so that it can be done at home during online learning, so that learning objectives can still be achieved even though it is not carried out in the laboratory. The stages of research implementation in this study is explained in Figure 1.

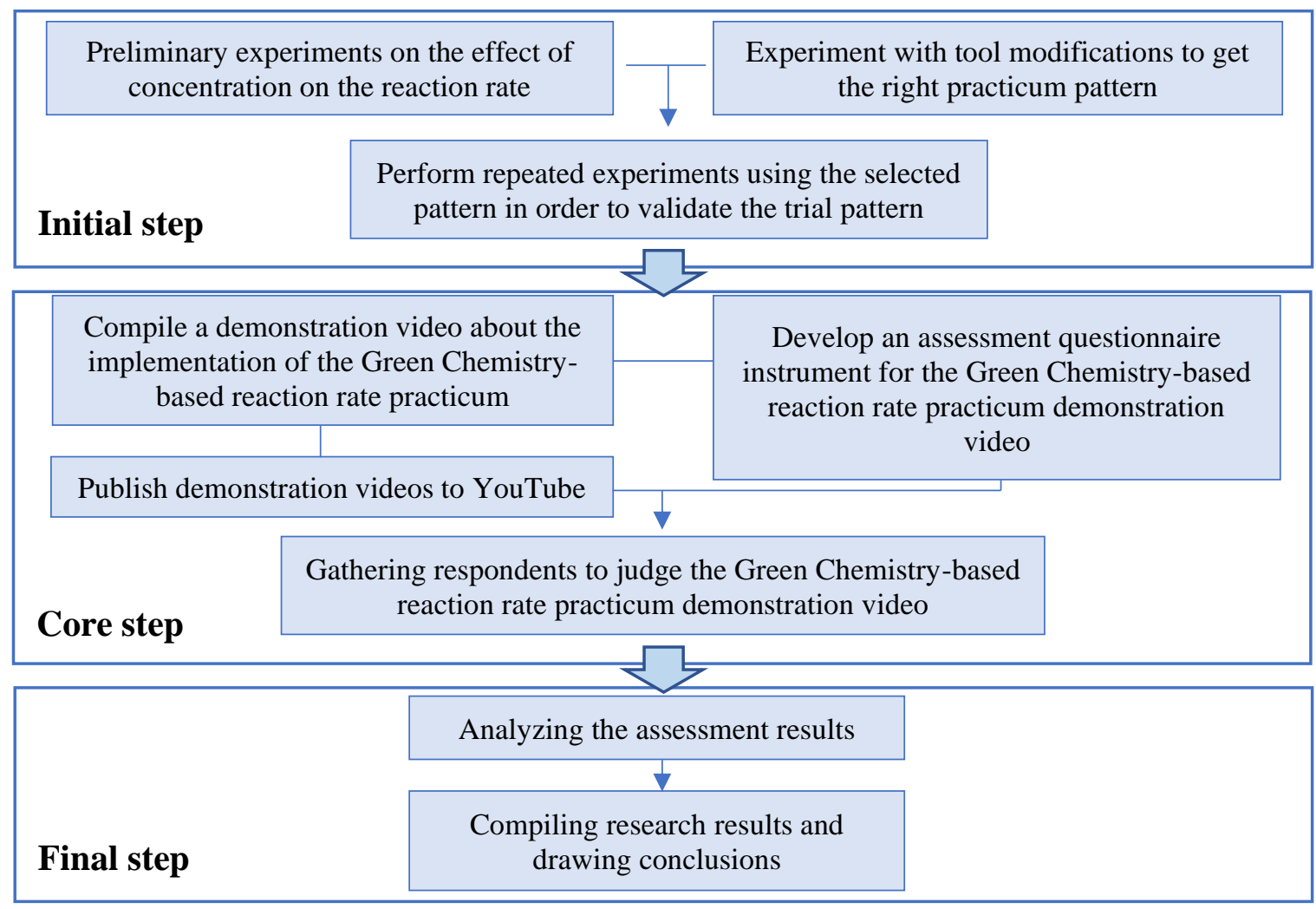

Figure 1. Research steps 
The questionnaire used in this study is valid and reliable, this questionnaire is valid as evidenced by the calculated $r$ value greater than the $r$ table value, with a value of 0.644 and 0.361 , respectively, this questionnaire also has moderate reliability, with an r11 value of 0.439. The mechanism for implementing this research is explained at the following points.

\subsection{Practicum Video Making}

\subsubsection{Implementation of the Green Chemistry-Based Reaction Rate Practicum}

The first step is to carry out a reaction rate experiment to determine the reaction order based on green chemistry. The tools and materials used in this experiment include used plastic bottles, jelly spoons, balloons with diameter lines, AQUA mineral water bottle caps, plastic funnels, $\mathrm{CH}_{3} \mathrm{COOH}$ (vinegar), and $\mathrm{NaHCO}_{3}$ (baking soda). These tools and materials are easy to find around students, so viewers of this video can practice this experiment at home.

\subsubsection{Making a Green Chemistry-Based Reaction Rate Practicum Demonstration Video}

The video is taken during the practicum. After getting data from observations, the researchers then edited the demonstration video of the practical implementation by adding voice and writing with the help of inshot and powerpoint applications. This video editing aims to make the practicum demonstration video easily understood and imitated by the audience.

\subsubsection{Publishing a Practicum Demonstration Video of Green Chemistry-Based Reaction Rate}

After the video editing process is complete, then the video is uploaded to the YouTube page publicly with the aim that the video can be seen by anyone and researchers can easily share the video link with respondents.

\subsubsection{Sharing Videos and Questionnaires to respondents}

Researchers share video links that have been uploaded on YouTube along with a google form link as a means to assess experimental videos by respondents. In this questionnaire, the identity of the respondent is not mentioned with the intention of giving freedom to the respondent and maintaining the confidentiality of the respondent.

\subsection{Respondent}

The sampling technique in this study is probability sampling. Probability sampling is a technique that provides equal opportunities for the selected population, in this case, higher education students as prospective chemistry teachers. The design used is the Simple Random Sampling design, the sample is taken at random without regard to the strata in the population [27]. The population in this study were students of the Chemistry Education study program at UIN Walisongo Semarang, and the sample was students of Chemistry Education Classes 18 and 20. So that the respondents in this study were students of Chemistry Education UIN Walisongo Semarang batches 18 and 20 who were taken randomly. The reason for using the Simple Random Sampling method is because the population taken is students who are all studying in the Chemistry Education study program, so that students' understanding of the topic of reaction order is on average the same. 


\subsection{Instrument}

The instrument used in this research is in the form of an assessment questionnaire for a reaction rate practicum demonstration video which contains the following assessment ranges:

Table 1. Scoring Range in The Questionnaire

\begin{tabular}{cc}
\hline Score & Category \\
\hline 1 & Very Poor \\
2 & Poor \\
3 & Moderate \\
4 & Good \\
5 & Very Good \\
\hline
\end{tabular}

The points of this questionnaire contain related information: 1) Completeness of the concept of reaction rate included in the experiment, 2) Tools and materials that are easy to obtain, 3) Experimental steps that can be followed by high school students, 4) Experiments can help students understand the concept of reaction rate, 5) Environmentally friendly principles.

\subsection{Data Analysis}

The final step of this research is data analysis. The data analysis technique used is inferential statistical technique, which is used to analyze sample data and the results are applied to the population. The results of this research in the form of a reaction rate practicum can be applied in the learning process for all students. The data from the assessment is analyzed to get answers from the existing problem formulations. The steps of data analysis activities are grouping data based on variables, tabulating data, presenting data carefully, and performing calculations [28]. The tool used to help process the data in this research is the Microsoft Excel application which can process data easily.

\section{RESULTS AND DISCUSSION}

\subsection{Experiment Description}

The purpose of the green chemistry-based reaction rate practicum is to prove the effect of concentration on the reaction rate. According to the collision theory, concentration can affect the rate of a reaction because when the concentration of one reactant is doubled, the number of collisions between particles will also increase twice, because in any volume there are twice as many molecules of one of the reactants that can collide with the molecules of the other reactant, so this causes the rate of the reaction to double [4]. This experiment will reveal what concentration affects the reaction rate, whether it is the concentration of $\mathrm{CH}_{3} \mathrm{COOH}$ or the concentration of $\mathrm{NaHCO}_{3}$. This experiment was carried out at a temperature of $25^{\circ} \mathrm{C}$, the practicum was carried out at one time so that there were no control variables that affected the experiment.
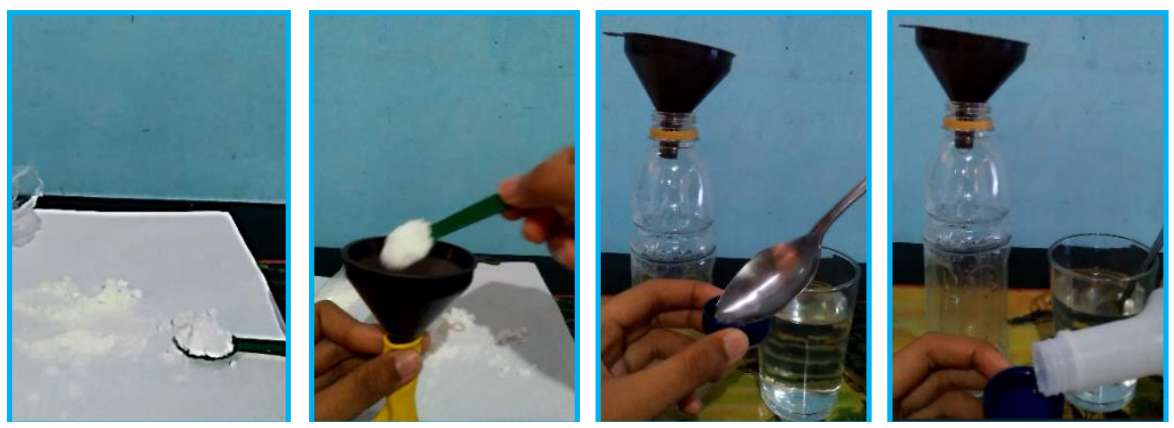

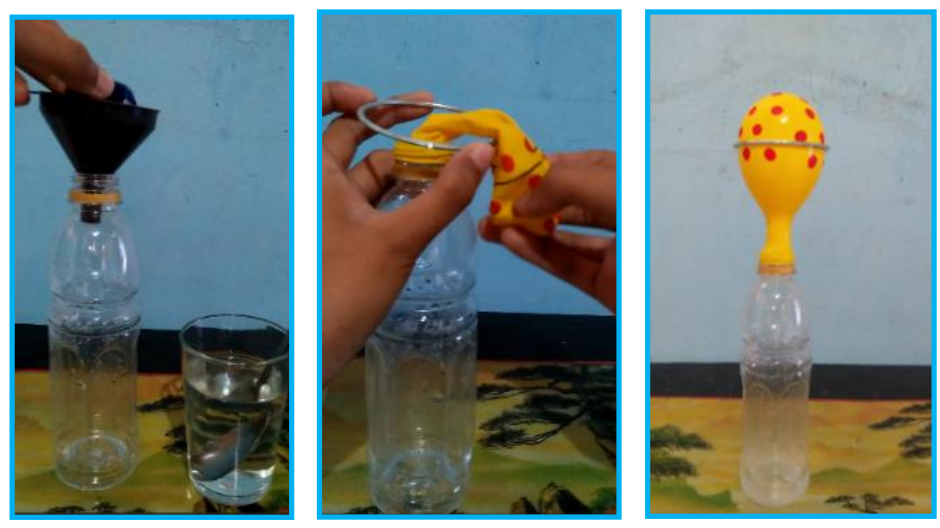

Figure 2. Practicum Implementation Mechanism

Based on the observation, it was found that the concentrations of $\mathrm{CH}_{3} \mathrm{COOH}$ and $\mathrm{NaHCO}_{3}$ both affect the reaction rate, but the concentration that greatly affects the reaction rate is the concentration of $\mathrm{CH}_{3} \mathrm{COOH}$, the higher the value of the $\mathrm{CH}_{3} \mathrm{COOH}$ concentration, the faster the reaction rate. It can also be seen that the volume of the solvent (water) greatly affects the rate of the reaction. This is because $\mathrm{NaHCO}_{3}$ is more easily decomposed by large volume solutions, so the reaction proceeds more quickly. After the observation data was obtained, the reaction order of $\mathrm{CH}_{3} \mathrm{COOH}$ and $\mathrm{NaHCO}_{3}$ was calculated. Based on the order calculation, it can be seen that the rate equation for the reaction between $\mathrm{CH}_{3} \mathrm{COOH}$ and $\mathrm{NaHCO}_{3}$ in the green chemistry-based reaction rate practicum is $r=k\left[\mathrm{CH}_{3} \mathrm{COOH}\right]^{0,35}\left[\mathrm{NaHCO}_{3}\right]^{0,25}$. This shows that the reaction rate is proportional to the power of 0.35 and 0.25 of $\mathrm{CH}_{3} \mathrm{COOH}$ and $\mathrm{NaHCO}_{3}$.

The reaction in this experiment is an acid-base reaction, between a weak acid and a weak base. $\mathrm{CH}_{3} \mathrm{COOH}$ is a compound with weak acid properties and $\mathrm{NaHCO}_{3}$ is a weak base compound. Both of these compounds are weak because they are only partially ionized in water [4]. The reaction between $\mathrm{CH}_{3} \mathrm{COOH}$ and $\mathrm{NaHCO}_{3}$ is an acid-base neutralization reaction, because this reaction produces water and salt so that in this reaction a neutral salt is produced. The formula in this experiment is:

$\mathrm{NaHCO}_{3}(\mathrm{~s})+\mathrm{CH}_{3} \mathrm{COOH}(\mathrm{aq}) \rightarrow \mathrm{CH}_{3} \mathrm{COONa}(\mathrm{aq})+\mathrm{CO}_{2}(\mathrm{~g})+\mathrm{H}_{2} \mathrm{O}(\mathrm{l})$

Based on reaction (1), it is known that the reaction between $\mathrm{CH} 3 \mathrm{COOH}$ and $\mathrm{NaHCO} 3$ produces $\mathrm{CO} 2$ gas. This is proven by inflating the balloon when the experiment is carried out. The reaction between the two is an endothermic reaction, that is, a reaction that absorbs energy. Endothermic reactions in an adiabatic vessel can lower the temperature of the system, and in a diathermic vessel under isothermic conditions, energy flows from the surroundings to the system as heat. This is evidenced by the cold sensation in the plastic bottle and the appearance of water dew on the outside of the bottle. This endothermic reaction indicates that the products resulting from this reaction are less stable than the reactants, so heat will be absorbed by the reacting mixture from the environment.

\subsection{Survey Results}

After the questionnaire was distributed to 30 respondents, the results of the judgment were obtained from the reaction rate practicum demonstration video. These results are shown in Figure 3. 


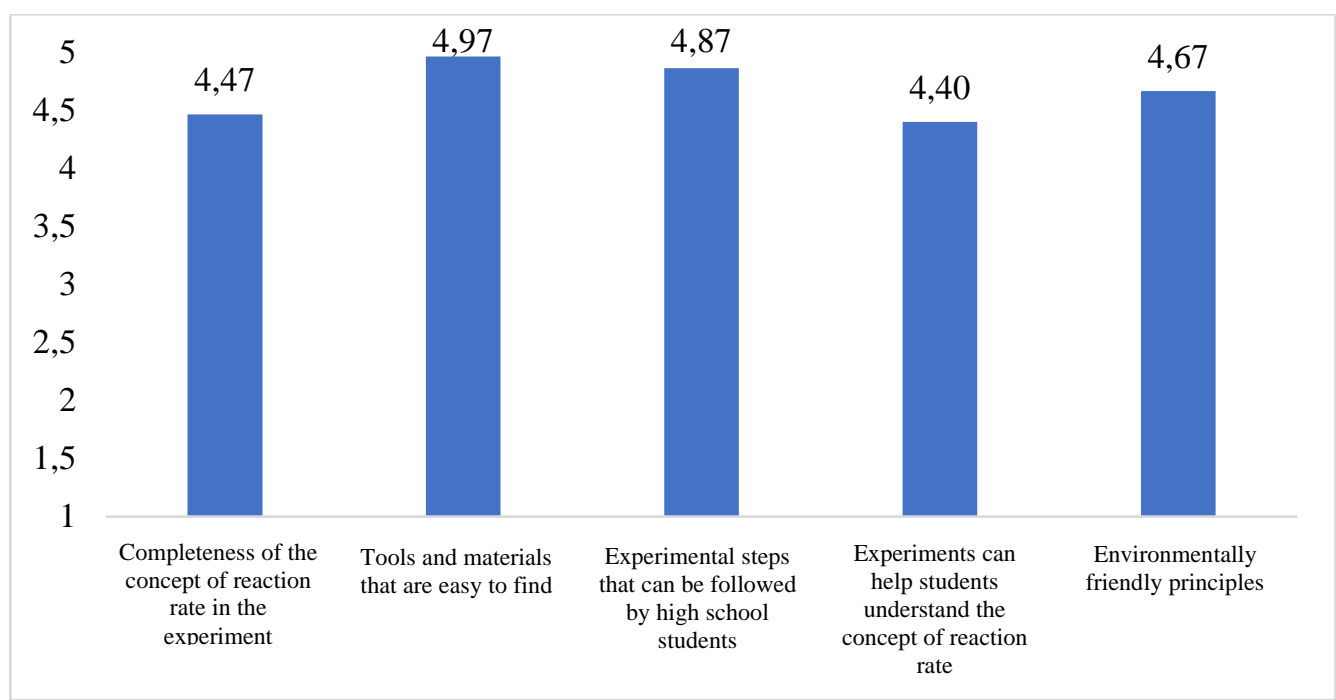

Figure 3. Diagram of Respondents' Assessment Results

The questionnaires that have been shared contain questions with some basic information as follows:

\subsubsection{Completeness of the Concept of Reaction Rate in the Experiment}

Based on the results of the respondent's questionnaire, an average value of 4.47 out of 5. This value is not perfect, it means that the practicum has not fully discussed the concept of reaction rate, this is because the experiments carried out only prove one of the factors that affect the reaction rate, where the factors that should affect the reaction rate based on the collision theory include the concentration and surface area of the contact area, temperature, pressure and volume, as well as the catalyst [11]. This study only uses the concentration factor because the experiment is focused on calculating the reaction order. The following are the results obtained from the respondents.

\begin{tabular}{|rccccc|}
\hline $60 \%$ & & & & $46,70 \%$ & $50 \%$ \\
$40 \%$ & & & & \\
$20 \%$ & $0 \%$ & $0 \%$ & $3,30 \%$ & & \\
$0 \%$ & Question & Question & Question & Question & Question \\
& Number 1 & Number 2 & Number 3 & Number 4 & Number 5 \\
\hline
\end{tabular}

Figure 4. Assessment on The Completeness of The Concept

\subsubsection{Tools and Materials that are Easy to Find}

Based on the results of the questionnaire, obtained 4.97 points out of 5 points (near perfect). This shows that the practicum is carried out using easily available tools and materials so that this experiment can be carried out at home during the implementation of online learning. Independent practicum by students can be done easily by utilizing the resources of tools and practicum materials that are easy to find from home [29]. The following are the results of the assessment obtained from the respondents. 


\begin{tabular}{|c|c|c|c|c|c|}
\hline \multicolumn{6}{|l|}{$\begin{array}{l}150 \% \\
100 \%\end{array}$} \\
\hline \multirow{2}{*}{$\begin{array}{r}50 \% \\
0 \%\end{array}$} & $0 \%$ & $0 \%$ & $0,00 \%$ & $3,30 \%$ & \\
\hline & $\begin{array}{l}\text { Question } \\
\text { Number } 1\end{array}$ & $\begin{array}{l}\text { Question } \\
\text { Number } 2\end{array}$ & $\begin{array}{l}\text { Question } \\
\text { Number } 3\end{array}$ & $\begin{array}{l}\text { Question } \\
\text { Number } 4\end{array}$ & $\begin{array}{l}\text { Question } \\
\text { Number } 5\end{array}$ \\
\hline
\end{tabular}

Figure 5. Assessment on Tools and Materials

\subsubsection{Experiment Steps that can be Followed by Students}

Based on the results of the questionnaire, the average result was 4.87 out of 5 . This shows that this practicum has not been $100 \%$ practiced by students so it needs to be improved so that this experiment can really be imitated by high school students. This experimental video contains a demonstration of the implementation of the reaction rate practicum. The demonstration method is a method that explains the process by paying attention to the chronology of information, the demonstration method is effective for explaining a concept because it is practiced directly so that it can be followed by students. [30]. The following are the results of the assessment obtained from the respondents.

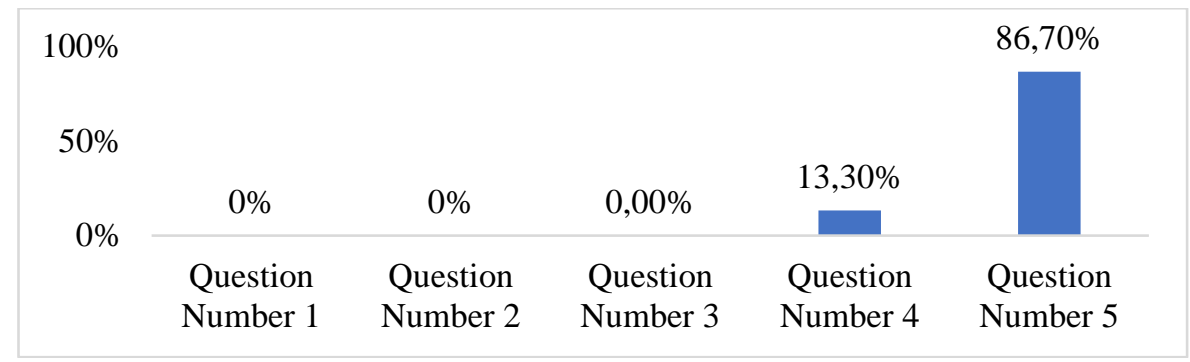

Figure 6. Assessment on Experiment Steps

\subsubsection{Experiment can help students to understand the concept of reaction rate}

Based on this information, the results obtained from respondents are 4.40 out of 5 . This shows that the practicum video can help students understand the concept of reaction rate but is not optimal, because the video only explains the implementation of the practicum and the results of observations to the calculation of the reaction order only. There was no further discussion regarding the reasons for each step, so some respondents found it difficult to understand the concept. The following are the results of the assessment obtained from the respondents.

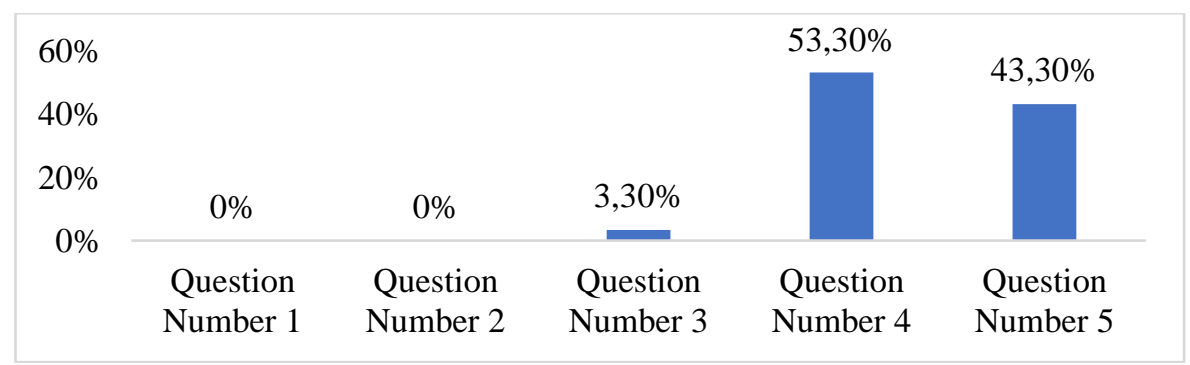

Figure 7. Assessment on Reaction Rate Concept Information Obtained from the Video 


\subsubsection{Environmentally friendly principles}

In this question, respondents gave a score of 4.67 out of 5. The materials used in this experiment were acetic acid and sodium bicarbonate. According to L. Sapei, acetic acid is an organic acid that is not corrosive and is more environmentally friendly [31]. Acetic acid does not last long at ambient temperature and is easily damaged, but produces water as a by-product so there is no residual activity [32]. Experiments that apply the principle of green chemistry are experiments that use environmentally friendly materials and low concentrations, safe implementation procedures, and do not produce waste that is harmful to health and the environment [33]. Figure 8 shows the results of the respondents' assessments.

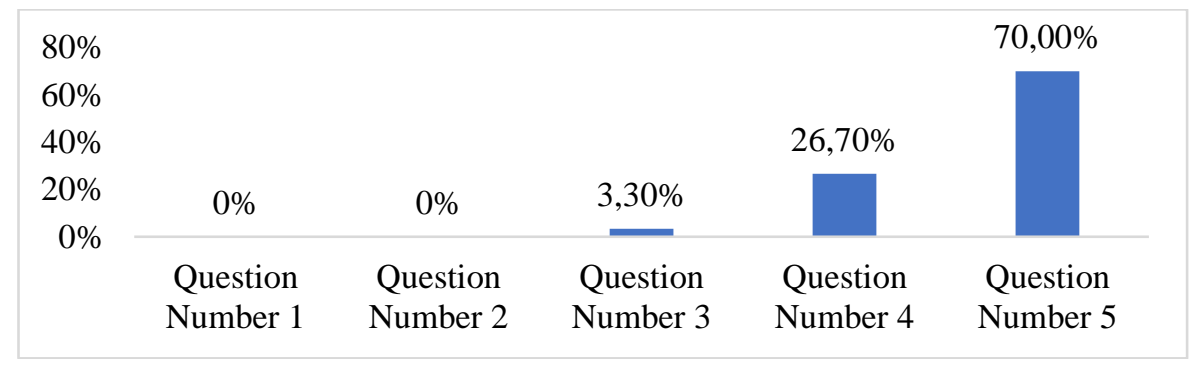

Figure 8. Assessment on Environmentally Steps Principles

After the survey was conducted, this practicum received a lot of positive responses from the respondents, so that this practicum could be a solution for teachers or educators to implement it in practical activities on the subject of reaction rates, especially in determining the reaction order.

\section{CONCLUSION}

The purpose of this research is to develop a reaction rate practicum design that focuses on the topic of determining the order of a reaction. This practicum is structured to provide solutions to teachers related to environmentally friendly practicums that use materials and methods that are easy to obtain and easy to follow. Based on the respondents, it was found that the practicum developed was very practical and feasible to be applied. This is shown from the average of the questionnaire results which reached 4.68 out of a maximum score of 5. Thus, it can be concluded that the developed practicum can be recommended to be applied in online learning activities. In this reaction rate experiment, we have not discussed all the factors that affect the reaction rate, only the concentration factor, so that further researchers are expected to develop experiments to prove other factors that affect the reaction rate, of course with tools, materials, and procedures that are easy to find. Because during this pandemic learning is done online, so it is necessary to do a different and easier practicum method.

\section{REFERENCES}

[1] S. Sakti, A. H. Fatah, and M. E. Anggraeni, "Analisis Materi Ajar Konsep Laju Reaksi Pada Buku Teks Kimia SMA/MA," J. Ilm. Kanderang Tingang, vol. 11, no. 1, pp. 78-91, 2020, doi: 10.37304/jikt.v11i1.77.

[2] I. Farida, R. R. Zahra, and F. S. Irwansyah, "Experiment Optimization on the Reaction Rate Determination and Its Implementation in Chemistry Learning To Develop Science Process Skills," J. Pendidik. Sains Indones. (Indonesian J. Sci. Educ., vol. 8, no. 1, pp. 67-77, 2020, doi: 10.24815/jpsi.v8i1.15608. 
[3] R. L. Stowe, D. G. Herrington, R. L. McKay, and M. M. Cooper, “Adapting a CoreIdea Centered Undergraduate General Chemistry Curriculum for Use in High School," J. Chem. Educ., vol. 96, pp. 1318-1326, 2019, doi: 10.1021/acs.jchemed.9b00071.

[4] Sri Mulyanti dan Moh. Nurkhozin, Kimia Dasar Jilid 2. Bandung: Alfabeta, 2016.

[5] J. Jusniar, "Misconceptions in Rate of Reaction and their Impact on Misconceptions in Chemical Equilibrium," Eur. J. Educ. Res., vol. 9, no. 4, pp. 1405-1423, 2020, doi: 10.12973/eu-jer.9.4.1405.

[6] N. Fauziah, Y. Andayani, and A. Hakim, "Problem-based learning tools oriented of green chemistry in reaction rate concept," J. Phys. Conf. Ser., vol. 1402, no. 5, 2019, doi: 10.1088/1742-6596/1402/5/055054.

[7] J. Iribe, T. Hamada, H. Kim, M. Voegtle, and C. A. Bauer, "Rolling the Dice: Modeling First- And Second-Order Reactions via Collision Theory Simulations in an Undergraduate Laboratory," J. Chem. Educ., vol. 97, no. 3, pp. 764-771, 2020, doi: 10.1021/acs.jchemed.9b00657.

[8] S. Summer, A. Shafi, and I. I. Naqvi, "SATL model lesson for teaching effect of temperature on rate of reaction," African J. Chem. Educ., vol. 4, no. 2, pp. 139-144144, 2014.

[9] M. V. Silalahi, "Development of E-Modules Based on Exe-Learning on Topics of Reaction Rate Against Student Learning Outcomes Mechanical Engineering," IJECA Int. J. Educ. Curric. Appl., vol. 3, no. 2, pp. 114-120, 2020.

[10] M. E. Emenike, C. P. Schick, A. G. Van Duzor, M. S. Sabella, S. M. Hendrickson, and L. S. Langdon, "Leveraging undergraduate learning assistants to engage students during remote instruction: Strategies and lessons learned from four institutions," J. Chem. Educ., vol. 97, no. 9, pp. 2502-2511, 2020, doi: 10.1021/acs.jchemed.0c00779.

[11] M. L. Kawamura, A. G. Alleyne, and E. Sutanto, "An educational laboratory experimental system for teaching chemical reaction process dynamics and control," ASEE Annu. Conf. Expo. Conf. Proc., vol. 2017-June, 2017, doi: 10.18260/1-2-27554.

[12] S. Mulyani, Liliasari, Wiji, M. N. Hana, and E. Nursa'Adah, "Improving students' generic skill in science through chemistry learning using ict-based media on reaction rate and osmotic pressure material," J. Pendidik. IPA Indones., vol. 5, no. 1, pp. 150-156, 2016, doi: 10.15294/jpii.v5i1.5804.

[13] C. J. Harwood, J. Meyer, and M. H. Towns, "Assessing student learning in a rapidly changing environment: Laboratories and exams," J. Chem. Educ., vol. 97, no. 9, pp. 3110-3113, 2020, doi: 10.1021/acs.jchemed.0c00651.

[14] B. Dekorver, A. Chaney, and D. Herrington, "Strategies for teaching chemistry online: A content analysis of a chemistry instruction online learning community during the time of covid-19," J. Chem. Educ., vol. 97, no. 9, pp. 2825-2833, 2020, doi: 10.1021/acs.jchemed.0c00783.

[15] C. I. C. Crucho, J. Avó, A. M. Diniz, and M. J. S. Gomes, "Challenges in teaching organic chemistry remotely," J. Chem. Educ., vol. 97, no. 9, pp. 3211-3216, 2020, doi: 10.1021/acs.jchemed.0c00693.

[16] K. M. Jegstad, A. T. Sinnes, and S. M. Gjøtterud, "Science teacher education for sustainable development: From intensions to realisation," Nord. Stud. Sci. Educ., vol. 14, no. 4, pp. 350-367, 2018, doi: 10.5617/nordina.3263.

[17] K. Mageswary, Z. H. Ismail, and N. Mohamed, "Green Chemistry: Educating Prospective Science Teachers in Education for Sustainable Development at School 
of Educational Studies, USM," J. Soc. Sci., vol. 7, no. 1, pp. 42-50, 2011, doi: 10.3844/jssp.2011.45.53.

[18] J. J. MacKellar, D. J. C. Constable, M. M. Kirchhoff, J. E. Hutchison, and E. Beckman, "Toward a Green and Sustainable Chemistry Education Road Map," J. Chem. Educ., vol. 97, no. 8, pp. 2104-2113, 2020, doi: 10.1021/acs.jchemed.0c00288.

[19] M. P. Utomo, "Green Chemistry dengan Kimia Katalisis," Pros. Semin. Nas. Penelitian, Pendidik. dan Penerapan MIPA, pp. 167-173, 2010.

[20] S. W. Al Idrus, A. A. Purwoko, S. Hadisaputra, and E. Junaidi, "Pengembangan Modul Praktikum Kimia Lingkungan Berbasis Green Chemistry Pada Mata Kuliah Kimia Lngkungan," J. Pijar Mipa, vol. 15, no. 5, p. 541, 2020, doi: 10.29303/jpm.v15i5.2171.

[21] A. C. Putri, "Pengaplikasian Prinsip-Prinsip Green Chemistry dalam Pelaksanaan Pembelajaran Kimia sebagai Pendekatan untuk Pencegahan Pencemaran Akibat Bahan-Bahan Kimia dalam Kegiatan Praktikum di Laboratorium," J. Creat. Student, vol. 2, no. 2, pp. 67-73, 2019.

[22] M. Simpson, L. Mccracken, M. Butler, N. York, and A. Innes, "Project Leader * Editors."

[23] A. Syarifah, Kinerja Praktikum Kimia Berbasis Green Chemistry Untuk Sma / Ma Kelas Xi Materi. 2018.

[24] F. Muhammad and A. Rusilowati, "Penerapan Pendekatan MIKiR Materi Getaran dan Gelombang untuk Meningkatkan Literasi Sains dan Kreativitas Siswa SMP," Unnes Phys. Educ. J., vol. 3, no. 3, pp. 77-83, 2014.

[25] W. Rahma, "Pengaruh Penggunaan Metode Kooperatif Window Shopping Terhadap Partisipasi Bimbingan Konseling Klasikal," J. Penelit. Pendidik. Indones., vol. 2, no. 2, pp. 1-8, 2017.

[26] A. S. Wahyuningsih and J. Rohmah, "Pengembangan Modul Praktikum Kimia Dasar Berbasis Green Chemistry Untuk Mahasiswa Calon Guru Ipa," J. Pena Sains, vol. 4, no. 1, p. 43, 2017, doi: 10.21107/jps.v4i1.2857.

[27] L. Cohen, L. Manion, and K. Morrison, Research Methods in Education 8th Edition, 8th ed. New York: Routledge Taylor \& Francis Group, 2018.

[28] J. W. Creswell, Educational research: Planning, conducting, and evaluating quantitative and qualitative research, vol. 4. New York: Pearson, 2012.

[29] S. Giri and P. Dutta, "Identifying Challenges and Opportunities in Teaching Chemistry Online in India amid COVID-19," 2020, doi: 10.1021/acs.jchemed.0c00720.

[30] Q. Umam and S. Sunaryo, "Toplesfer: Media Sederhana Untuk Mendukung Pembelajaran Demonstrasi Pada Pelajaran Geografi," J. Ilm. Ilmu Sos., vol. 5, no. 2, p. 81, 2019, doi: 10.23887/jiis.v5i2.22430.

[31] L. Sapei, Padmawijaya, K. Samuel., A. Sutejo, and L. Theresia, "Temperatur Leaching Menggunakan Asam Asetat," J. Tek. Kim., vol. 9, no. 2, pp. 38-43, 2015.

[32] H. Pujisiswanto et al., "Pengaruh Asam Asetat Sebagai Herbisida Pratumbuh Terhadap Perkecambahan Jagung Effect of Acetic Acid as Pre-Emergence Herbicide on Maize Germination," vol. 15, no. November 2014, pp. 61-67, 2016.

[33] A. S. Wahyuningsih, S. Poedjiastoeti, and S. Suyono, "the Effect of Green Chemistry Laboratory Learning on Pre-Service Chemistry Teachers' Environmental Value Orientations and Creative Thinking Skill," JPPS (Jurnal Penelit. Pendidik. Sains), vol. 5, no. 1, p. 848, 2017, doi: 10.26740/jpps.v5n1.p848858. 